\title{
Unilateral ovarian leiomyoma in a 14-year-old adolescent: A rare case report
}

14 yaşında bir adölesanda unilateral ovaryen leiomyom: Nadir bir olgu sunumu

\author{
Aşkı Ellibeş Kaya ${ }^{1}$, Sabri Berkem Ökten ${ }^{2}$, Alper Başbuğ ${ }^{1}$, Mehmet Gamsızkan ${ }^{3}$, Ozan Doğan ${ }^{4}$, Hasan Bakı ${ }^{5}$
}

\begin{abstract}
Leiomyomas are benign mesenchymal tumors mostly seen in the uterus. Uterine leiomyomas are one of the most common reasons of pelvic masses seen in women whereas ovarian leiomyomas are so rare that among all benign ovarian tumors, it accounts only 0.5 $1 \%$. It is mostly seen between ages of 20 to 65 years which premenopausal women consist almost $85 \%$ of them.

In this case, we aimed to present a 14-year-old girl who was admitted to our clinic with a six months history of bilateral lower quadrant abdominal pain. In ultrasonographic evaluation, there was a solid mass with uterine echogenity extending from the posterior side of the uterus towards to the right adnexial area with diameters of $6 \mathrm{~cm} \times 5.5 \mathrm{~cm}$. The origin of the tumor could not be evaluated with ultrasonography and magnetic resonance imaging. Therefore, diagnostic laparoscopy with an intention to excise was performed. The tumor arising from the left ovary was removed with laparotomy and the final pathology was compatible with ovarian leiomyoma.

When we checked the literature our case is one of the youngest of all reported cases that was 14 years old and with unilateral feature differently from the most of the other published cases under age of 20.

Keywords: Adolescent, Ovarian leiomyoma, Pelvic pain, Unilateral
\end{abstract}

\section{Öz}

Leiomyomlar sıklıkla uterusta rastlanan benin mezenkimal tümörlerdir. Uterin leiomyomlar kadınlarda görülen pelvik kitlelerin en s1k nedenlerinden olsa da, over kaynaklı leiomyomlar oldukça nadir görülmekle birlikte bütün over kaynaklı benin tümörlerin yalnızca \%0,5 ila \%1'ini oluşturmaktadır. Genellikle 20-65 yaş grubunda görülmekte olup, \%85'ini premenopozal dönemdeki kadınlar oluşturmaktadır.

$\mathrm{Bu}$ olguda kliniğimize 6 aydır devam eden bilateral alt kadran karın ağrısı nedeniyle başvuran 14 yaşındaki bir k1z çocuğunu sunduk. Ultrasonografik görüntülemede uterus arka duvar komşuluğundan sağ adneksiyal bölgeye uzanım gösteren, uterin ekojenitesi olan solid görünümde $6 \times 5,5 \mathrm{~cm}$ boyutlarında bir kitle izlendi. Kitlenin kaynağının ultrason ve magnetik rezonans görüntüleme ile net belirlenememesi üzerine tanısal laparoskopi uygulandı. Sol over kaynaklı kitle laparotomi ile çıkarılıp patolojiye gönderildiğinde patoloji sonucu ovaryen leiomyom ile uyumlu çıktı.

Bildirilen vakalar içinde 14 yaşında olarak en genç vakalardan biri olma özelliği yanı sıra 20 yaş altı olup, genelde rastlanandan farklı olarak unilateral karakter taşıması ile farklılık göstermektedir.

Anahtar kelimeler: Adölesan, Ovaryen leiomyom, Pelvik ağrı, Unilateral
${ }^{1}$ Department of Obstetrics and Gynecology, Faculty of Medicine, Duzce University

${ }^{2}$ Department of Obstetrics and Gynecology, Baskent University Istanbul Health Practice and Research Center

${ }^{3}$ Department of Pathology, Faculty of Medicine, Duzce University

${ }^{4}$ Department of Obstetrics and Gynecology, University of Health Sciences Sisli Hamidiye Etfal Research and Training Hospital

${ }^{5}$ Department of Radiology, Faculty of Medicine, Duzce University

Informed Consent: The written consent was received from the patient who was presented in this study.

Hasta Onamı: Çalışmada sunulan hastadan yazılı onam alınmıştır.

Conflict of Interest: No conflict of interest was declared by the authors.

Çıkar Çatışması: Yazarlar çıkar çatışması bildirmemişlerdir.

Financial Disclosure: The authors declared that this case has received no financial support. Finansal Destek: Yazarlar bu olgu için finansal destek almadıklarını beyan etmişlerdir.

Geliş Tarihi / Received: 25.01.2018

Kabul Tarihi / Accepted: 21.02.2018

Yayın Tarihi / Published: 02.03.2018

Sorumlu yazar / Corresponding author Sabri Berkem Ökten

Adres/Address: Başkent Üniversitesi İstanbul Sağlık Uygulama ve Araştırma Merkezi Kadın Hastalıkları ve Doğum Polikliniği, Oymacı Sok.

No:2 34662, Altunizade, İstanbul, Türkiye.

Tel: +90 5334644504

e-posta: berkemokten@gmail.com

Copyright (C) ACEM 


\section{Introduction}

Ovarian leiomyomas are seen so rare that among all benign ovarian tumors, it accounts only $0.5-1 \%$ [1]. They are mostly unilateral, small and asymptomatic tumors and seen between ages of 20 to 65 years in which premenopausal women consist $85 \%$ of them. The youngest age reported being 3 years, only 7 cases were reported under the age of 20 [2,3]. Ovarian leiomyomas are mostly asymptomatic and are detected accidentally during physical examination, imaging or operation for other pathologies [1]. Since ovarian leiomyomas are rare and have gross and histological similarities with other spindle cell tumors like thecoma/fibroma, sometimes the diagnosis could be difficult [4]. When compared with older patients, pediatric / adolescent patients mostly present with bilateral disease and uterine leiomyomas do not usually co-exist [5]. In contrast to older patients, ovary-preserving surgery is also a crucial issue in adolescent patients [6]. In this case, we aimed to present a unilateral ovarian leiomyoma in a 14-year-old girl adolescent patient.

\section{Case report}

A 14-year-old girl with a body mass index of $27 \mathrm{~kg} / \mathrm{m} 2$ was admitted to our clinic with a 6 months history of lower quadrant abdominal pain which especially increases during menstrual periods. She has regular menses and constipation from time to time. She had no abdominal guarding and rebound tenderness on her abdominal examination. The patient had a fatty waist and no abdominal mass was felt with palpation at the supine position. Rectal examination at lithotomy position was performed and a solid and fixed mass at the pouch of Douglas was palpated. Complete blood count and laboratory parameters were normal. Serum tumor markers i.e. CA-125 and CA19-9 were within the normal reference range and $\beta$-hCG was negative.

In pelvic ultrasonography, the uterus and both ovaries were found to be normal in size. There was a solid mass with uterine echogenity extending from the posterior side of the uterus towards to the right adnexial area with diameters of $6 \mathrm{~cm} \times 5.5$ $\mathrm{cm}$. Magnetic resonance imaging (MRI) scan with contrast was done with an initial diagnosis of pedunculated subserous leiomyoma or adnexial mass. MRI showed a $6.5 \times 5.5 \mathrm{~cm}$ wellcircumscribed mass at the right adnexial area with unknown origin that exhibited iso-hyper intense on T1-weighted imaging, hyper-intense and mostly heterogeneous signal intensity on T2weighted imaging and there was no intensity loss when evaluated with fat-suppression. In dynamic contrast evaluation, postcontrast MRI showed irregular peripheral contrasted tumoral lesion. The lesion had areas containing fat density and in the central part, fluid density was detected. MRI could not differentiate the origin of the tumor as well and it was reported that the mass had an echogenity of a leiomyoma but could as well be a teratoma (Figure 1).

Diagnostic laparoscopy was performed. When inspected, the pedunculated mass was located at the right side of the pouch of Douglas arising from the left ovary showing band like adhesions to both the left ovary and posteriorly to the pouch of Douglas. Due to the solid mass showing adhesions to the neighboring structures, laparoscopic surgery was converted to laparotomy to avoid any potential risks. A lower midline incision was made and peritoneal washing sample was collected. The adhesions were separated by sharp and blunt dissection. In inspection, the uterus was normal in size and both the Fallopian tubes and the ovaries were normal. There was a solid mass with a diameter of $7 \mathrm{~cm}$ attached to the left ovary with a $3 \mathrm{~cm}$ long and $1 \mathrm{~cm}$ thick peduncule (Figure 2). The mass was grabbed, cut and tied from its peduncule and examined via frozen pathological analysis. Due to the benign pathological features of the mass, the operation was ended with abdominal closure. During the postoperative period, there was no complication and the patient was discharged uneventfully.

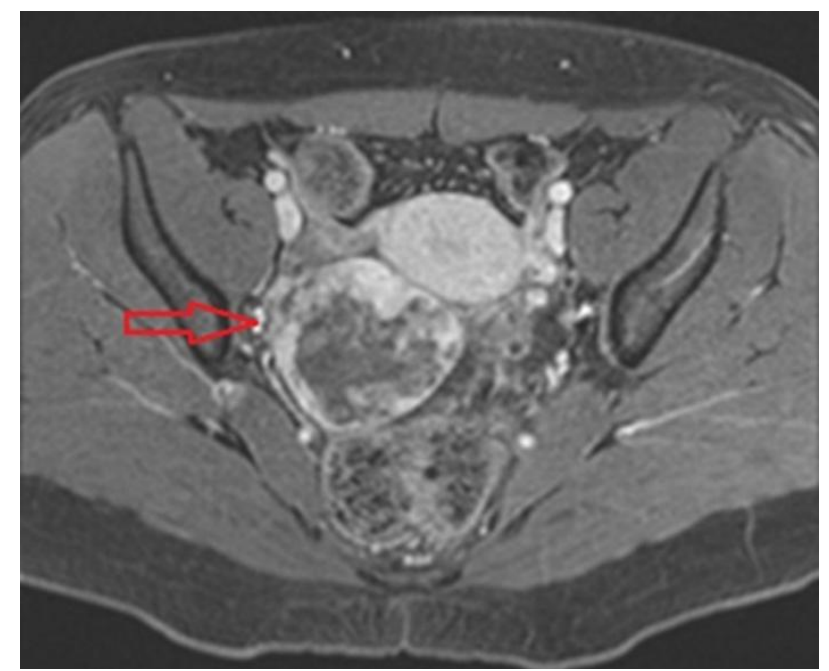

Figure 1: Pre-operative MRI showing the mass located at the right adnexial area (red arrow).

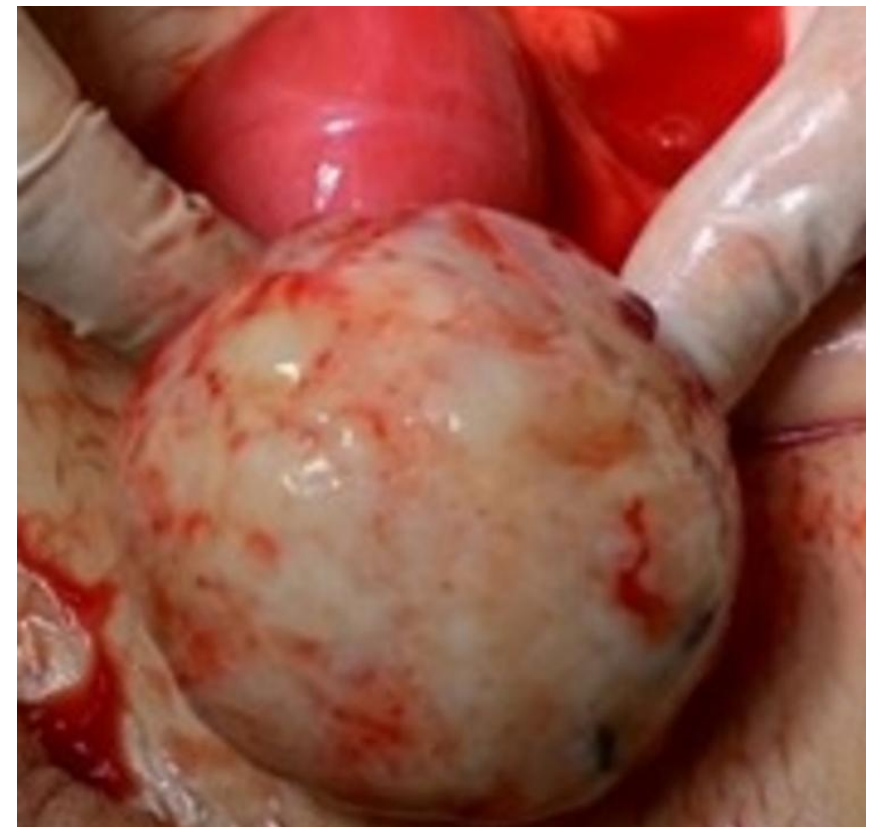

Figure 2: Peroperative view of the ovarian mass.

\section{Pathology}

The specimen was $7 \times 6 \times 5 \mathrm{~cm}$ in size with lobular contour and the cut surface was grey-white colored, whorled macroscopically. In histopathologic examination, a mesenchymal tumor was observed with irregular bundles and whorling of spindle shaped cells with no atypia or mitotic activity. Immunohistochemically, the tumor cells were strongly positive for desmin and smooth muscle actin and negative for calretinin and inhibin immunoexpression (Figure 3). Final pathology was compatible with leiomyoma. 


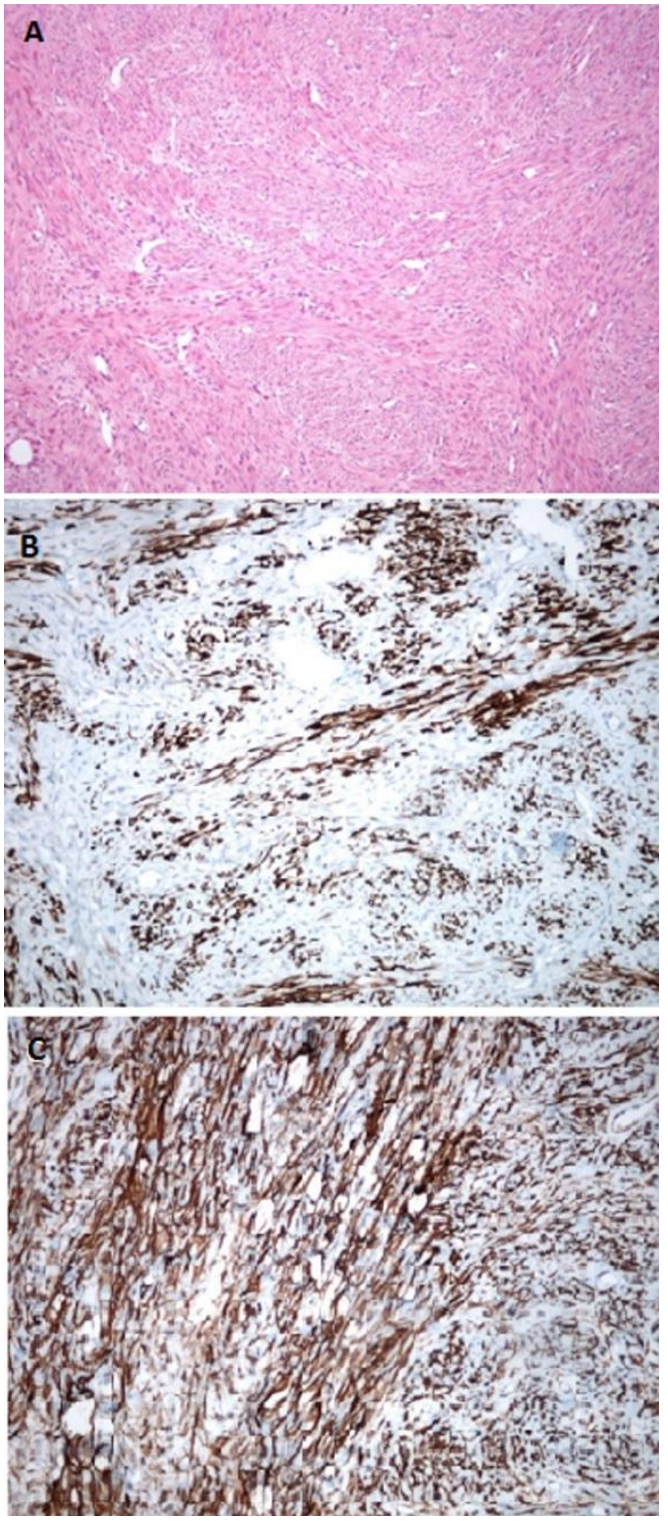

Figure 3: (a) Histopathological interlacing bundles of spindle shaped cells with no atypia nor mitotic activity, fascicles of smooth muscle cells (HEx100), (b) desmin immunoexpression in neoplastic cells (x200), (c) marked immunoreactivity for smooth muscle actin (x200).

\section{Discussion}

Ovarian leiomyomas are benign tumors which are seen so rare that it consists about $0.5-1 \%$ of all ovarian neoplasms [1].The strongest theory about their origin is smooth muscle cells in the vessels of ovarian hilar body whereas it might also arise from smooth muscle cells or multipotential cells in the ovarian stroma, cells in the ovarian ligament, cortical smooth muscle metaplasia or undifferentiated germ cells [6].

About 80 cases have been reported in the literature worldwide till 2012 mostly being premenopausal [7]. The youngest age reported being 3 years, only 7 cases were reported under the age of $20[2,3]$. Our case is one of the youngest among all reported cases as being 14 years old.

Most of these tumors do not cause any complaints so they can be detected during a routine physical examination or incidentally during surgery or autopsy [8]. Clinical presentations for symptomatic cases can be abdominal pain varying from mild to severe, palpable mass, acute symptoms due to torsion or necrosis, hydroureteronephrosis due to the great-size of the tumors [4]. Our patient was admitted to our clinic with a six months history of bilateral lower quadrant abdominal pain which especially increases during menstrual periods.

Usually there is an associated uterine leiomyoma in older patients whereas mostly no co-existing uterine leiomyoma is seen in pediatric/adolescent group [5]. Ultrasound visualizes ovarian leiomyomas as isoechoic with the myometrium hence making it difficult to distinguish them from uterine leiomyomas and other solid tumors. In diagnosis of indistinct pelvic masses, MRI can be useful [9]. In our case, the uterus was normal but MRI also could not distinguish the mass well enough to state a clear diagnosis. Also the mass was reported as located at the right side of the uterus even though it was originated from the left ovary. It was due to pedunculated feature of the tumor. Other smooth muscle processes that can involve the ovary include intravenous leiomyomatosis, parasitic uterine leiomyomas, leiomyomatosis peritonealis disseminata and ovarian smooth muscle metaplasia [5].

Ovarian leiomyomas mostly show a unilateral character in overall whereas in most of the cases in literature, patients at pediatric/young adult group have bilateral ovarian leiomyomas [5]. Our case showed a unilateral feature with only left ovarian leiomyoma.

Hysterectomy and bilateral salpingo-oophorectomy can be the ideal surgical approach for middle-aged or older women whereas ovarian sparing techniques can be chosen for younger patients [6]. In most of the case reports in literature, laparotomy was performed for the removal of the mass, whereas in some cases laparoscopic approach was successfully performed $[5,6]$. In our case, because of the dense adhesions of the tumor to the surrounding tissues and need of ovary preservation due to patient's young age, we performed laparotomy after diagnostic laparoscopy. In our case, the pedunculated feature of the mass helped us to preserve the ovarian tissues.

In conclusion, a primary unilateral ovarian leiomyoma is a rare condition especially in adolescents and can be difficult to diagnose. Sometimes the imaging techniques like ultrasound and MRI can be inadequate to differentiate the origin of the tumor. We think that with or without any symptoms, immediate evaluation and removal of the solid masses with an unknown origin should be made when seen especially in young patients in order to avoid the risk of potential malignancy and ovarian torsion that makes preservation of the ovaries impossible when lately diagnosed.

\section{References}

1. Taskin MI, Ozturk E, Yildirim F, Ozdemir N, Inceboz U. Primary ovarian leiomyoma: A case report. Int J Surg Case Rep 2014; 5: 665-8.

2. Blue NR, Felix JC, Jaque J. Primary ovarian leiomyoma in a premenarchaladolescent: first reported case. J Pediatr Adolesc Gynecol 2014 ; 27: e87-8.

3. Lerwill MF, Sung R, Oliva E, Prat J, Young RH. Smooth muscle tumors of theovary: a clinicopathologic study of 54 cases emphasizing prognostic criteria, histologic variants, and differential diagnosis. Am J Surg Pathol 2004; 28: 1436-51

4. Guney M, Ozsoy M, Oral B, Mungan T, Kapucuoğlu N. Unilateral primary ovarian leiomyoma inadolescent: a case report. Arch Gynecol Obstet 2007; 275:507.

5. Wei C, Lilic N, Shorter N, Garrow E. Primary ovarian leiomyoma: a rare cause of ovarian tumor in adolescence. J Pediatr Adolesc Gynecol 2008; $21: 33$

6. Bettaiah R, Kurkuri SN, Vanishree BR, Chaithra TM. An uncommon entity of primary ovarian fibroid: a case report. Int $\mathrm{J}$ Reprod Contracept Obstet Gynecol 2016; 5: 927-32.

7. Kim MJ, Na ED, Lee YJ, Kim ML, Seong SJ, Kim JY. A case of ovarian leiomyoma treated with laparoscopic mass excision. Korean J Obstet Gynecol 2012; 55: 218-23.

8. Lim S, Jeon H. Bilateral primary ovarian leiomyoma in a young woman: case report and literature review. Gynecol Oncol 2004; 95 : 733.

9. Yasushi K, Noriyuki T, Masako S, Kaei N, Isao M. Magnetic resonance imaging findings in leiomyoma of the ovary: a case report. Arch Gynecol Obstet 2005; 273: 298-300. 